\title{
Dynamic Changes of Orexin A and Leptin in Obese Children during Body Weight Reduction
}

\author{
J. BRONSKÝ $Y^{1,2}$, J. NEDVÍDKOVÁ ${ }^{3}$, H. ZAMRAZILOVÁ ${ }^{4}$, M. PECHOVÁ ${ }^{2}$, \\ M. CHADA ${ }^{2,5}$, K. KOTAŠKKA ${ }^{2}$, J. NEVORAL ${ }^{1}$, R. PRŮŠS ${ }^{2}$ \\ ${ }^{1}$ Department of Pediatrics, Second Medical Faculty, Charles University and University Hospital \\ Motol, Prague, Czech Republic, ${ }^{2}$ Department of Clinical Biochemistry and Pathobiochemistry, \\ Second Medical Faculty, Charles University and University Hospital Motol, Prague, Czech \\ Republic, ${ }^{3}$ Institute of Endocrinology, Prague, Czech Republic, ${ }^{4}$ Department of Anthropology, \\ Faculty of Natural Sciences, Charles University, Prague, Czech Republic, and ${ }^{5}$ Department of \\ Pediatrics, University of Erlangen-Nuremberg, Erlangen, Germany
}

Received September 13, 2005

Accepted January 11, 2006

On-line available February 23, 2006

\begin{abstract}
Summary
In this study, we describe changes of plasma levels of the hypothalamic neuropeptide orexin $\mathrm{A}$ in obese children during the reduction of body weight and its relationship to other biochemical and anthropometrical parameters. We measured orexin A fasting plasma levels by the RIA method in 58 obese children - 33 girls and 25 boys; mean age $13.1 \pm 0.38$ years (range 7-18.5) before and after 5 weeks of weight-reduction therapy. Leptin, IGF-1, and IGFBP-3 levels were measured in all the subjects and were compared to orexin A levels and anthropometrical data. Average weight in subjects before weight-reduction was $74.2 \pm 2.79 \mathrm{~kg}$ and after weight-loss $67.4 \pm 2.60 \mathrm{~kg}(\mathrm{p}<0.0001)$. Orexin A levels before the therapy were $33.3 \pm 1.97 \mathrm{pg} / \mathrm{ml}$ and after the therapy $51.7 \pm 3.07 \mathrm{pg} / \mathrm{ml}(\mathrm{p}<0.0001)$. Levels of orexin A were not significantly different between girls and boys $(\mathrm{p}=0.7842)$. We found negative correlation between orexin $\mathrm{A}$ and age $(\mathrm{r}=-0.5395 ; \mathrm{p}<0.0001)$, body height $(\mathrm{r}=-0.4751 ; \mathrm{p}=0.0002)$, body weight $(\mathrm{r}=-0.4030 ; \mathrm{p}=0.0017)$ and BMI $(r=-0.2607 ; p=0.0481)$. No correlation was found between orexin A and IGF-1, IGFBP-3 or leptin. Orexin A plasma levels increased during body weight loss, whereas the reverse was true for leptin levels. These findings support the hypothesis that orexin A may be involved in regulation of nutritional status in children.
\end{abstract}

Key words

Orexin A $\bullet$ Hypocretin $1 \bullet$ Leptin $\bullet$ Obesity $\bullet$ Nutritional Status

\section{Introduction}

Orexin A (hypocretin 1) is a hypothalamic neuropeptide composed of 33 aminoacid residues $(\mathrm{FW}=3562)$ (Sakurai et al. 1998) that is involved in the regulation of food intake and sleep-wake cycle (Nishino et al. 2000, Yanagisawa and Beuckmann 2002, Higuchi et al. 2002, Cai et al. 2002). Previous studies showed that intracerebroventricular administration of orexin A increases food intake in rodents (Dube et al. 1999, 
Table 1. Anthropometrical parameters in obese subjects before and after reduction of body weight.

\begin{tabular}{lcccccc}
\hline & GB & GA & BB & BA & AB & AA \\
\hline Body weight $(\mathrm{kg})$ & $74.2 \pm 3.04$ & $67.8 \pm 2.80$ & $74.2 \pm 5.15$ & $66.8 \pm 4.85$ & $74.2 \pm 2.79$ & $67.4 \pm 2.60$ \\
BMI $\left(\mathrm{kg} / \mathrm{m}^{2}\right)$ & $28.6 \pm 0.64$ & $26.1 \pm 0.59$ & $29.1 \pm 1.09$ & $26.1 \pm 1.06$ & $28.8 \pm 0.59$ & $26.1 \pm 0.56$ \\
\hline
\end{tabular}

Data are mean \pm S.E.M. GB - girls before reduction of body weight; GA - girls after reduction of body weight; BB - boys before reduction of body weight; $B A$ - boys after reduction of body weight; $A B$ - all before reduction of body weight; $A A$ - all after reduction

Haynes et al. 1999, Sweet et al. 1999) and intraperitoneal injection of a selective antagonist against type 1 orexin receptor or central injection of anti-orexin antibody significantly reduced food consumption in rats (Haynes $e t$ al. 2000, Yamada et al. 2000). Fasting increases preproorexin mRNA content in the lateral hypothalamus (Sakurai et al. 1998).

Orexin A was also detected in human plasma (Arihara et al. 2001) and decreased plasma levels of orexin A were described in adult obese subjects compared to healthy controls (Adam et al. 2002). Komaki et al. (2001) reported increased plasma levels of orexin A in adult fasting non-obese subjects during 10 days of fasting, which was followed by the decrease of orexin A levels during subsequent refeeding. Recently, it was shown that orexin A participates in the regulation of growth hormone secretion both in vitro (Chen and $\mathrm{Xu}$ 2003) and in vivo (Seoane et al. 2004, Lopez et al. 2004).

Leptin is a hormone produced by adipocytes that reflects the amount of body fat in the organism. It acts through receptors on hypothalamic neurons mainly in nucleus arcuatus. Neurons containing orexin A are situated downstream on this regulatory pathway (Bluher and Mantzoros 2004, Funahashi et al. 2003a,b, Yamanaka et al. 2000). Thus, we expect the changes in orexin A levels as a consequence of decreased body weight in obese subjects.

Obesity in childhood is a condition closely related to a further increased risk of various components of the metabolic syndrome in adulthood. Regulatory mechanisms that contribute to the development of obesity in childhood are partially revealed ( $\mathrm{O}^{\prime}$ Rahilly and Farooqi 2000), but many parts of the regulatory pathway remain unknown. In this study we show the changes of orexin A plasma levels during reduction of body weight in obese children and adolescents. All the abovementioned studies have been performed in adult subjects. Changes of orexin A plasma levels in obese children have not yet been reported. We also describe a relationship of orexin A plasma levels to other biochemical and anthropometrical parameters of nutritional status.

\section{Methods}

\section{Subjects}

We recruited 58 obese subjects (33 girls and 25 boys) undergoing weight-reduction therapy in health resort. We included in the study all the patients with body weight / body height ratio above 97th percentile according to standards for Czech children population based on the 5th nation-wide anthropological survey performed by National Institute of Public Health, Prague (Lhotská et al. 1994). Mean age of our subjects was $13.6 \pm 0.49$ years (range 7.8-18.1) in girls and $12.4 \pm 0.58$ years (range 7.0-18.5) in boys. Mean body height was $160.0 \pm 1.96 \mathrm{~cm}$ (range 134.6-177.6) in girls and $157.2 \pm 3.09 \mathrm{~cm}$ (range 126.8-178.7) in boys, respectively. Body weight and body mass index before and after reduction therapy are shown in Table 1.

Reduction of body weight was achieved during 5 weeks in a health resort using both decrease of food intake (low-caloric balanced diet ranging from 1200 to $1700 \mathrm{kcal}$ per day according to age) and enhanced energy expenditure (running, swimming, indoor and outdoor ball games, aerobic, at least $180 \mathrm{~min}$ per day). No medication was used to decrease body weight in the subjects. Written informed consent was obtained from parents of each of the participants.

Ten $\mathrm{ml}$ of fasting venous blood were withdrawn into 2 tubes $(5 \mathrm{ml}$ in plasma tubes containing EDTA and aprotinin (Antilysin, Spofa) and $5 \mathrm{ml}$ in a standard serum tubes (S-Monovette, Sarstedt)) from a cubital vein between 7:00-9:00 $\mathrm{h}$ at the time of admission to health resort and after 5 weeks of reduction program. Samples were centrifuged by $4000 \mathrm{x} \mathrm{g}$ for $10 \mathrm{~min}$ at $4{ }^{\circ} \mathrm{C}$. Separated plasma and serum were immediately frozen and stored at $-80^{\circ} \mathrm{C}$.

\section{Laboratory methods}

Orexin A concentrations were measured in 
duplicate after the extraction procedure. Acidified plasma using $1 \%$ trifluoroacetic acid (TFA) was centrifuged and supernatant was loaded on a SEP-COLUMN containing $200 \mathrm{mg}$ of C18 (Code RK-SEPCOL-1, Diagnostics Inc., Lake Forest, CA, USA) washed by $1 \%$ TFA and eluted by $60 \%$ acetonitrile in $1 \%$ TFA. The eluants were evaporated to dryness in a speed vacuum centrifuge from Heto (Melsungen, Germany). The residues were dissolved in RIA buffer for radioimmunoassay. We used commercially available RIA kit (Phoenix Pharmaceuticals, Belmont, CA, USA). The radioimmunoassay is based on competitive-binding principle and makes use of polyclonal rabbit antibodies against human orexin $\mathrm{A}$ and goat anti-rabbit antibody to separate bound and free fraction. Human orexin A was used as standard. The intra-assay and inter-assay variations were $5.2 \%$ and $14.2 \%$, respectively, and the lowest detectable concentration was $4 \mathrm{pg} / \mathrm{ml}$. There was no cross-reactivity with the fragment 16-33 of human orexin A, with orexin B, agouti-related protein amide (83-132), neuropeptide $\mathrm{Y}$, alpha-MSH and human leptin.

Leptin was measured in serum using commercially available human leptin RIA kit (Linco Research, Inc., Missouri, USA) based on competitivebinding principle. The intra-assay and inter-assay variations were $4.7 \%$ and $6.2 \%$, respectively, and the range of detectable concentrations declared by the producer is $0.5-100 \mathrm{ng} / \mathrm{ml}$. The cross-reactivity with mouse and rat leptin is less than $0.2 \%$ and there is no cross-reactivity with human insulin, proinsulin, C-peptide, glucagon or IGF-1. Recovery declared by the producer is $103-105 \%$.

Insulin-like growth factor-1 (IGF-1) was measured in serum using IRMA (Beckman-Coulter, France) and IRMA method (Diagnostic Systems Laboratories, Inc., USA) was used to detect serum IGF binding protein-3 (IGF BP-3). These methods are routinely performed in our biochemical laboratory.

\section{Anthropometry and statistics}

Anthropometrical measurements were performed immediately after blood withdrawal. Body weight and body height were measured by standard techniques (calibrated weighing machine and stadiometer), in underwear and without shoes. Body mass index (BMI) was counted as body weight $(\mathrm{kg})$ divided by the square of body height $\left(\mathrm{m}^{2}\right)$. Because the range of age of our subjects was wide and the changes of anthropometrical parameters are not linear during childhood and puberty, we counted standard deviation scores (SDS) for body height, body weight, and body mass index to use it in our correlation analyses. SDS were calculated from reference standards for Czech children population mentioned above (Lhotská et al. 1994).

Statistical analysis was performed using Prism 4.0 statistical software (Graph Pad Software, Inc.). Results are reported as mean \pm S.E.M. All the values were normally distributed. The correlations were tested by Pearson's correlation coefficient; the differences within groups were tested using paired t-test and differences between groups using unpaired t-test. Welch's correction was used in cases of significantly different variances. $\mathrm{P}<0.05$ value was considered statistically significant.

\section{Results}

\section{Anthropometrical data}

Boys and girls were comparable in age $(\mathrm{p}=0.1147$, n.s. $)$, body height $(\mathrm{p}=0.4491$, n.s. $)$, body weight ( $\mathrm{p}=0.9987$, n.s. - after Welch's correction), and BMI ( $\mathrm{p}=0.6736$, n.s. - after Welch's correction). Both in girls and boys, changes of body weight and BMI during reduction period were highly significant (all $\mathrm{p}<0.0001$ ). According to changes of body weight, we divided patients into two groups: low-responders (LR; 23 girls GLR, 12 boys - BLR) who lost less than $10 \%$ of initial body weight $(7.8 \pm 0.38 \%)$ and high-responders (HR; 10 girls - GHR, 13 boys - BHR) who lost more than $10 \%$ of initial body weight $(11.8 \pm 0.32 \%)$. The difference between LR and HR group concerning weight loss was statistically significant $(\mathrm{p}<0.0001)$.

\section{Plasma orexin A concentrations}

Plasma orexin A concentrations in girls before reduction of body weight (GB) were $32.8 \pm 2.24 \mathrm{pg} / \mathrm{ml}$ (range 9.7-67.3) and after reduction (GA) 48.8 \pm 4.12 $\mathrm{pg} / \mathrm{ml}$ (range 12.9-96.9) $(\mathrm{p}=0.0003)$. In boys before reduction of body weight $(\mathrm{BB})$ the concentrations were $34.0 \pm 3.54 \mathrm{pg} / \mathrm{ml}$ (range 4.6-74.3) and after reduction (BA) $55.5 \pm 4.59 \mathrm{pg} / \mathrm{ml}$ (range 15.3-96.0) $(\mathrm{p}<0.0001)$. When both groups were analyzed together, orexin A levels were $33.3 \pm 1.97 \mathrm{pg} / \mathrm{ml}$ (all before $-\mathrm{AB}$ ) and $51.7 \pm 3.07 \mathrm{pg} / \mathrm{ml}$ (all after $-\mathrm{AA})$, respectively $(\mathrm{p}<0.0001)$ (Fig. 1). Plasma levels of orexin $\mathrm{A}$ in $\mathrm{AB}$ correlated significantly with AA $(r=0.4089 ; p=0.0014)$. 


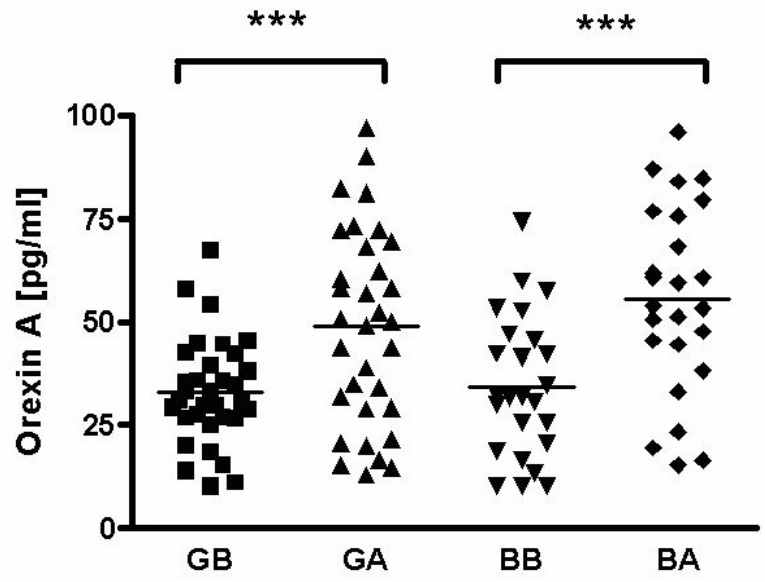

Fig. 1. Plasma levels of orexin $A$ before and after reduction of body weight. GB - girls before reduction of body weight; GA girls after reduction of body weight; $\mathrm{BB}$ - boys before reduction of body weight; BA - boys after reduction of body weight. Plasma levels of orexin $A$ are significantly higher after reduction of body weight in both girls*** $(p=0.0003)$ and boys*** $(p<0.0001)$
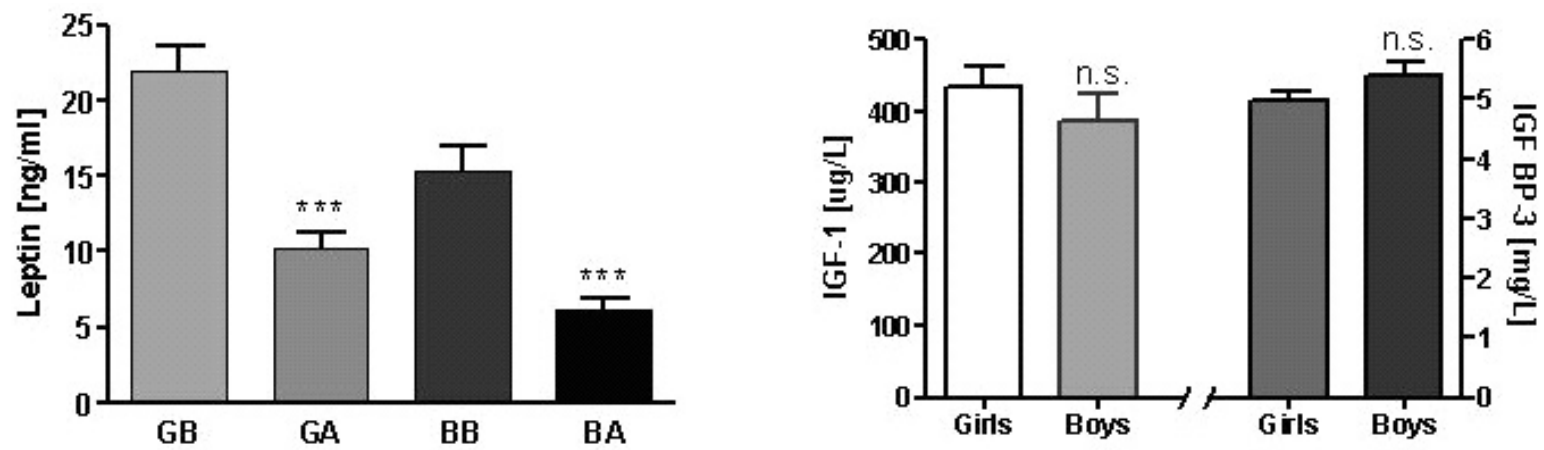

Fig. 2. Serum levels of leptin before and after reduction of body weight and serum levels of IGF-1 and IGF BP-3. GB - girls before reduction of body weight; GA - girls after reduction of body weight; BB - boys before reduction of body weight; BA - boys after reduction of body weight. Serum levels of leptin are significantly lower after reduction of body weight in both girls $* * *(p<0.0001)$ and boys $^{* * *}(\mathrm{p}<0.0001)$. Levels of IGF-1 and IGF BP-3 are not significantly different between girls and boys (n.s.).
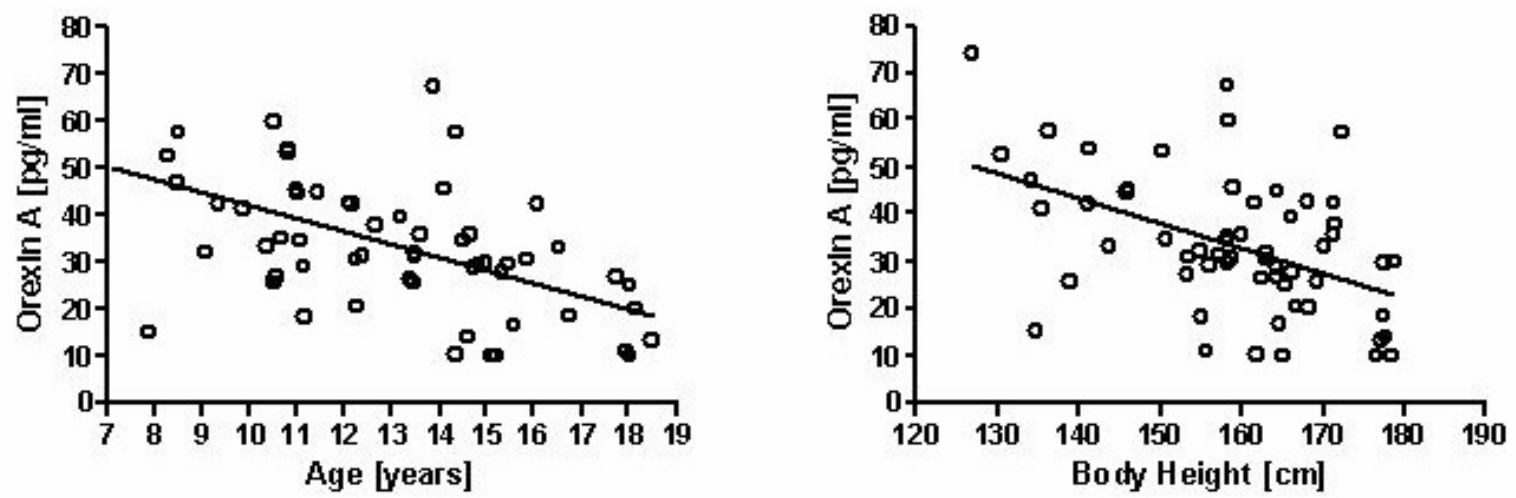

Fig. 3. Correlation between plasma orexin $A$ levels and age, body height. Negative correlations between orexin A plasma levels and age $(r=-0.5395 ; p<0.0001)$ or body height $(r=-0.4751 ; p=0.0002)$.

\section{Serum leptin, IGF-1 and IGF BP-3 concentrations}

Serum leptin concentrations in GB were $21.9 \pm 1.79 \mathrm{ng} / \mathrm{ml}$ and in GA $10.2 \pm 1.14 \mathrm{ng} / \mathrm{ml}(\mathrm{p}<0.0001)$. In $\mathrm{BB}$ the concentrations were $15.4 \pm 1.65 \mathrm{ng} / \mathrm{ml}$ and in BA $6.2 \pm 0.73 \mathrm{ng} / \mathrm{ml}(\mathrm{p}<0.0001)$. When both groups were analyzed together, the leptin levels were 19.1 \pm 1.30 (AB) and $8.4 \pm 0.76 \mathrm{ng} / \mathrm{ml}(\mathrm{AA})$, respectively $(\mathrm{p}<0.0001)$.

Leptin levels were significantly lower in boys than in girls both before $(p=0.0126)$ and after $(p=0.0053$, after Welch's correction) reduction of body weight (Fig. 2a). Serum IGF-1 levels in girls were $431.8 \pm 31.86$ $\mu \mathrm{g} / \mathrm{l}$ and in boys $386.6 \pm 39.47 \mu \mathrm{g} / \mathrm{l}$. IGF BP-3 levels in girls were $5.0 \pm 0.16 \mathrm{mg} / \mathrm{l}$ and in boys $5.4 \pm 0.23 \mathrm{mg} / \mathrm{l}$. Both IGF-1 and IGF BP-3 were measured only before reduction of body weight and there was no significant difference between girls and boys either in IGF-1 

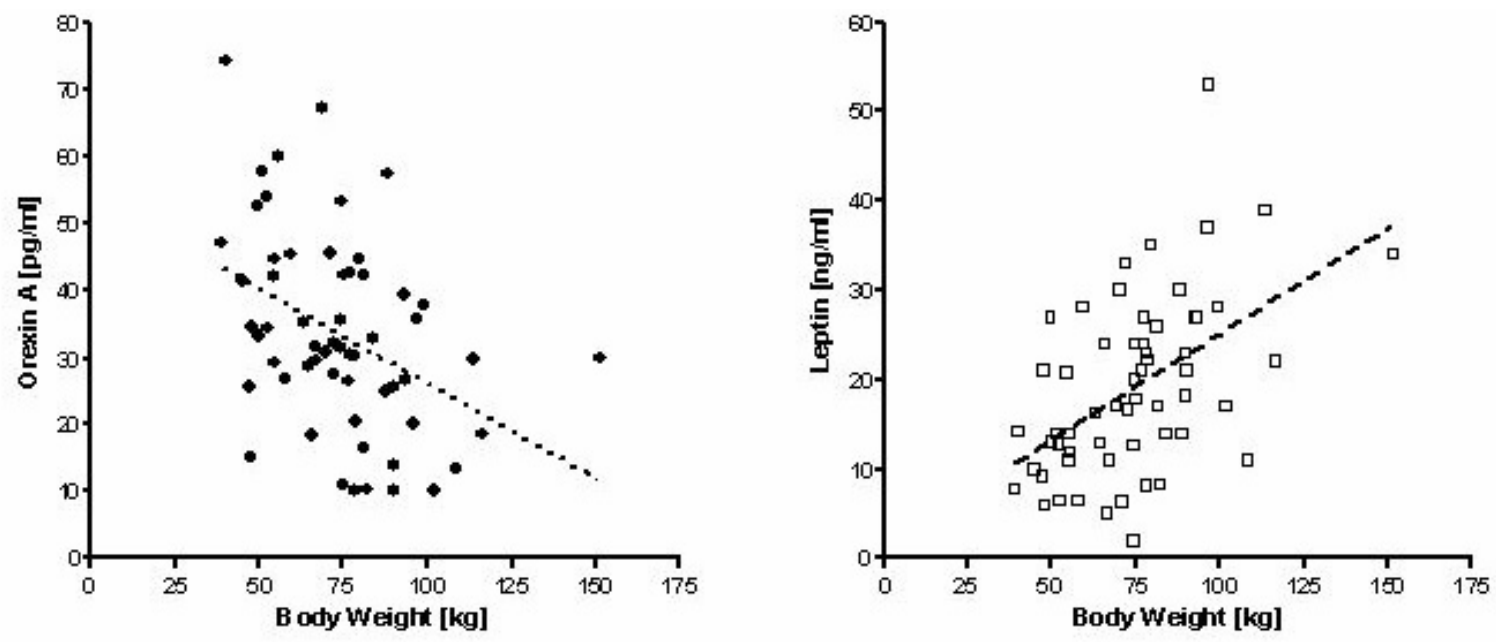

Fig. 4. Correlation between body weight and plasma orexin $A$ levels or serum leptin levels. Plasma orexin $A$ concentrations correlate negatively with body weight $(r=-0.4030 ; p=0.0017)$, whereas leptin concentrations are positively related to body weight $(r=0.5068$; $\mathrm{p}<0.0001)$.

$(\mathrm{p}=0.3716)$ or in IGF BP-3 ( $\mathrm{p}=0.1600)$ (Fig. 2b).

\section{Relationship to age and gender}

In our subjects, we found a strong negative correlation between orexin A levels and age $(r=-0.5395$; $\mathrm{p}<0.0001$ ) (Fig. 3a). Orexin A levels were not significantly different between boys and girls neither before $(\mathrm{p}=0.7842$, after Welch's correction) nor after $(p=0.2842)$ reduction of body weight, although in boys mean orexin A levels were slightly higher both before and after reduction of body weight.

\section{Correlations with anthropometric parameters}

We found a negative correlation between orexin A levels and body height $(r=-0.4751 ; p=0.0002)$ (Fig. 3b). Plasma orexin A concentrations correlate negatively with body weight $(\mathrm{r}=-0.4030 ; \mathrm{p}=0.0017)$ and BMI ( $\mathrm{r}=-0.2607 ; \mathrm{p}=0.0481)$ in the opposite manner to leptin ( $\mathrm{r}=0.5068 ; \mathrm{p}<0.0001$ and $\mathrm{r}=0.5764 ; \mathrm{p}<0.0001$, respectively). Correlation between orexin $\mathrm{A}$, leptin and body weight is shown in Figure 4 a,b. When all the data were converted to SD scores, no relationship was found between orexin A levels and SDS of body height $(\mathrm{r}=0.07795 ; \quad \mathrm{p}=0.5608), \quad$ SDS of body weight $(r=-0.03772 ; p=0.7786)$ or SDS of BMI $(r=-0.02343$; $\mathrm{p}=0.8614)$. On the contrary, leptin correlated positively both with SDS of body height $(r=0.3175 ; p=0.0152)$, SDS of body weight $(\mathrm{r}=0.6251 ; \mathrm{p}<0.0001)$ and SDS of BMI $(r=0.5445 ; p<0.0001)$. In the HR group, we found a higher increase in orexin A levels when compared to LR group, both in girls (20.5 \pm 6.31 vs. $14 \pm 5.02 \mathrm{pg} / \mathrm{ml}$, $\mathrm{p}=0.4585)$ and boys (23.5 \pm 6.56 vs. $19.3 \pm 5.36 \mathrm{pg} / \mathrm{ml}$, $\mathrm{p}=0.6281$ ), but this difference was not significant. Neither the change of leptin serum levels differed significantly between HR and LR group both in girls $(p=0.1778)$ and boys $(p=0.4126)$. When both girls and boys were considered together in the HR group, there was a tendency to negative correlation found between increase of orexin A and decrease of leptin levels ( $\mathrm{r}=-0.3849$, $\mathrm{p}=0.0698)$.

\section{Correlations with biochemical parameters}

There was no correlation found between plasma orexin A levels and serum leptin levels either before $(\mathrm{r}=-0.04193 ; \mathrm{p}=0.7547)$ or after weight reduction $(\mathrm{r}=-0.2249 ; \mathrm{p}=0.0897)$. We did not find any correlation between these two parameters even when the HR and LR groups were analyzed separately. There was no correlation found between orexin A plasma levels and either IGF-1 $(r=-0.03414 ; p=0.7992)$ or IGF BP-3 $(r=0.07766 ; p=0.5623)$ serum levels.

\section{Discussion}

In this study, we have shown for the first time the changes of orexin A plasma levels in obese children during the reduction of body weight. Our results support the hypothesis that the production of orexin A may be influenced by the changes of body weight, but we did not prove that orexin A levels are related to circulating serum leptin levels. Although it was previously shown that neurons producing orexin A are in a close relationship to neurons expressing leptin receptors (Funahashi et al. 2003b), there are probably more complex regulatory 
mechanisms involved in the regulation of orexin A production (Archer et al. 2002, Kok et al. 2003). There may be other regulatory peptides (either peripheral ghrelin, cholecystokinin or central - neuropeptide Y, agouti-related protein) which may influence production of orexin A in the hypothalamus and further studies are needed to identify such factors. Negative correlation of orexin A levels and body height, body weight and BMI of the subjects disappears when the data are converted to SDS scores. Thus, it is likely that this effect may be explained by age-related changes of orexin $\mathrm{A}$ in our subjects.

Moreover, detected plasma levels of orexin A may not precisely reflect hypothalamic expression of orexin A, although it crosses blood-brain barrier by simple diffusion (Kastin and Akerstrom 1999). Expression of orexin A was also shown in other tissues different from central nervous system, such as testis (Karteris et al. 2004, Johren et al. 2001, Mitsuma et al. 2000). This fact may explain slightly higher orexin A levels in boys shown in our study, in spite of the fact that orexin A levels were not significantly different between girls and boys. These findings correspond to results obtained in studies performed in adult subjects (Higuchi et al. 2002, Arihara et al. 2001, Orel et al. 2004).

In our study, we found a negative correlation between orexin A levels and age. Matsumura et al. (2002) described a positive correlation between orexin A levels and age in adult subjects. On the other hand, Kanbayashi et al. (2002) in his paper did not find any differences in orexin A levels in cerebrospinal fluid in respect to age. Tomasik et al. (2004) published an analysis of orexin A and B plasma levels in children from newborns until adolescence. This paper shows the highest levels of orexins in neonates and in children during puberty with subsequent decrease. Our results in children aged 10-18 years are in agreement with the above paper, but there are probably many factors influencing orexin A levels in developing organism which need further investigation.

We have shown the presence of orexin $\mathrm{A}$ in plasma of children aged 7-18.5 years. Previously, it was shown that orexin A is present in cerebrospinal fluid of infants under 4 months of age (Kanbayashi et al. 2002) and another orexigenic peptide ghrelin is present in human cord blood (Chanoine et al. 2002). Tomasik et al. (2004) showed that orexin A is also detectable in plasma of children up to 7 years of age, but we did not include these subjects to confirm their data, because the analysis requires large amount of blood for extraction procedure.

Although orexin A was shown to regulate growth hormone $(\mathrm{GH})$ secretion both in vitro and in vivo (Chen and Xu 2003, Seoane et al. 2004, Lopez et al. 2004), we did not find any relationship between orexin A levels and IGF-1 or its binding protein 3 . We found a negative correlation between orexin A levels and body height, but this correlation was not significant after the conversion of data to SD score. However, IGF-1 production is only partially dependent on $\mathrm{GH}$ and in obese children it is also regulated by nutritional factors. Thus, the effect of orexin A on GH secretion need not be reflected in the relationship to IGF-1. To evaluate the relationship of orexin A and GH in our subjects, it would be necessary to measure fasting $\mathrm{GH}$ under standard conditions with respect to its diurnal variation.

We can conclude that orexin A is probably involved in the regulation of body weight in children. In our previous study we have shown that there are nutritional regulatory peptides which may influence other physiological functions of human organism and some of the synthetic analogues of these peptides are already used for therapeutical administration (Bronský and Průša 2004). Orexin A and its receptors are discussed as a potential target for development of drugs influencing food intake and nutritional status of the organism (Smart et al. 2002). Development of a standard detection method suitable for biochemical laboratories and further studies elucidating the role of orexin A in human organism can make this peptide a suitable biomarker for clinical practice.

\section{Acknowledgements}

This study was supported by research grants IGA MZ NE/7443-3, GAUK 59/2004C and Danone Institute. We would also like to thank Dr. Němcová from Poděbrady health resort for management of a group of subjects and Mrs. Riegrová, Tumlî̌rová, Havlíčková, and Rechová for excellent laboratory work.

\section{References}

ADAM JA, MENHEERE PP, VAN DIELEN FM, SOETERS PB, BUURMAN WA, GREVE JW: Decreased plasma orexin-A levels in obese individuals. Int J Obes 26: 274-276, 2002. 
ARCHER ZA, FINDLAY PA, RHIND SM, MERCER JG, ADAM CL: Orexin gene expression and regulation by photoperiod in the sheep hypothalamus. Regul Pept 104: 41-45, 2002.

ARIHARA Z, TAKAHASHI K, MURAKAMI O, TOTSUNE K, SONE M, SATOH F, ITO S, MOURI T: Immunoreactive orexin-A in human plasma. Peptides 22: 139-142, 2001.

BLUHER S, MANTZOROS CS: The role of leptin in regulating neuroendocrine function in humans. $J$ Nutr 134: 2469S-2474S, 2004.

BRONSKÝ J, PRŮŠA R: Amylin fasting plasma levels are decreased in patients with osteoporosis. Osteoporos Int 15: 243-247, 2004.

CAI XJ, LIU XH, EVANS M, CLAPHAM JC, WILSON S, ARCH JR, MORRIS R, WILLIAMS G.: Orexins and feeding: special occasions or everyday occurrence? Regul Pept 104: 1-9, 2002.

CHANOINE JP, YEUNG LP, WONG AC, BIRMINGHAM CL: Immunoreactive ghrelin in human cord blood: relation to anthropometry, leptin, and growth hormone. J Pediatr Gastroenterol Nutr 35: 282-286, 2002.

CHEN C, XU R: The in vitro regulation of growth hormone secretion by orexins. Endocrine 22: 57-66, 2003.

DUBE MG, KALRA SP, KALRA PS: Food intake elicited by central administration of orexins/hypocretins: identification of hypothalamic sites of action. Brain Res 842: 473-477, 1999.

FUNAHASHI H, TAKENOYA F, GUAN JL, KAGEYAMA H, YADA T, SHIODA S: Hypothalamic neuronal networks and feeding-related peptides involved in the regulation of feeding. Anat Sci Int 78: 123-138, $2003 \mathrm{a}$.

FUNAHASHI H, YAMADA S, KAGEYAMA H, TAKENOYA F, GUAN JL, SHIODA S: Co-existence of leptin- and orexin-receptors in feeding-regulating neurons in the hypothalamic arcuate nucleus - a triple labeling study. Peptides 24: 687-694, $2003 \mathrm{~b}$.

HAYNES AC, JACKSON B, OVEREND P, BUCKINGHAM RE, WILSON S, TADAYYON M, ARCH JR: Effects of single and chronic intracerebroventricular administration of the orexins on feeding in the rat. Peptides 20: 1099-1105, 1999.

HAYNES AC, JACKSON B, CHAPMAN H, TADAYYON M, JOHNS A, PORTER RA, ARCH JR: A selective orexin-1 receptor antagonist reduces food consumption in male and female rats. Regul Pept 96: 45-51, 2000.

HIGUCHI S, USUI A, MURASAKI M, MATSUSHITA S, NISHIOKA N, YOSHINO A, MATSUI T, MURAOKA H, ISHIZUKA Y, KANBA S, SAKURAI T:_Plasma orexin-A is lower in patients with narcolepsy. Neurosci Lett 318: 61-64, 2002.

JOHREN O, NEIDERT SJ, KUMMER M, DENDORFER A, DOMINIAK P: Prepro-orexin and orexin receptor mRNAs are differentially expressed in peripheral tissues of male and female rats. Endocrinology 142: 33243331, 2001.

KANBAYASHI T, YANO T, ISHIGURO H, KAWANISHI K, CHIBA S, AIZAWA R, SAWAISHI Y, HIROTA K, NISHINO S, SHIMIZU T: Hypocretin-1 (orexin-A) levels in human lumbar CSF in different age groups: infants to elderly persons. Sleep 25: 337-339, 2002.

KARTERIS E, CHEN J, RANDEVA HS: Expression of human prepro-orexin and signaling characteristics of orexin receptors in the male reproductive system. J Clin Endocrinol Metab 89: 1957-1962, 2004.

KASTIN AJ, AKERSTROM V: Orexin A but not orexin B rapidly enters brain from blood by simple diffusion. J Pharmacol Exp Ther 298: 219-223, 1999.

KOK SW, OVEREEM S, VISSCHER TL, LAMMERS GJ, SEIDELL JC, PIJL H, MEINDERS AE: Hypocretin deficiency in narcoleptic humans is associated with abdominal obesity. Obes Res 11: 1147-1154, 2003.

KOMAKI G, MATSUMOTO Y, NISHIKATA H, KAWAI K, NOZAKI T, TAKII M, SOGAWA H, KUBO C: Orexin A and leptin change inversely in fasting non-obese subjects. Eur J Endocrinol 144: 645-651, 2001.

LHOTSKÁ L, BLÁHA P, VIGNEROVÁ J, ROTH Z, PROKOPEC M: 5th nation-wide anthropological survey 1991 in the Czech Republic: comparison with 1981 data. Cent Eur J Public Health 2: 95-99, 1994.

LOPEZ M, SEOANE LM, TOVAR S, NOGUEIRAS R, DIEGUEZ C, SENARIS R: Orexin-A regulates growth hormone-releasing hormone mRNA content in a nucleus-specific manner and somatostatin mRNA content in a growth hormone-dependent fashion in the rat hypothalamus. Eur J Neurosci 19: 2080-2088, 2004. 
MATSUMURA T, NAKAYAMA M, NOMURA A, NAITO A, KAMAHARA K, KADONO K, INOUE M, HOMMA T, SEKIZAWA K: Age-related changes in plasma orexin-A concentrations. Exp Gerontol 37: 1127-1130, 2002.

MITSUMA T, HIROOKA Y, KAYAMA M, MORI Y, YOKOI Y, RHUE N, PING J, IZUMI M, IKAI R, ADACHI K, NOGIMORI T: Radioimmunoassay for orexin A. Life Sci 66: 897-904, 2000.

NISHINO S, REPLEY B, OVEREEM S, LAMMERS GJ, MIGNOT E: Hypocretin (orexin) deficiency in human narcolepsy. Lancet 355: 39-40, 2000.

O'RAHILLY S, FAROOQI IS: Recent advances in the genetics of severe childhood obesity. Arch Dis Child 83: 31-34, 2000.

OREL M, LICHNOVSKÁ R, GWOZDZIEWICZOVÁ S, ZLÁMALOVÁ N, KLEMENTA I, MERKUNOVÁ A, HŘEBÍČEK J: Gender differences in tumor necrosis factor alpha and leptin secretion from subcutaneous and visceral fat tissue. Physiol Res 53: 501-505, 2004.

SAKURAI T, AMEMIYA A, ISHII M, MATSUZAKI I, CHEMELLI RM, TANAKA H, WILLIAMS SC, RICHARSON JA, KOZLOWSKI GP, WILSON S, ARCH JR, BUCKINGHAM RE, HAYNES AC, CARR SA, ANNAN RS, MCNULTY DE, LIU WS, TERRETT JA, ELSHOURBAGY NA, BERGSMA DJ, YANAGISAWA M: Orexins and orexin receptors: a family of hypothalamic neuropeptides and G-protein coupled receptors that regulate feeding behavior. Cell 92: 573-585, 1998.

SEOANE LM, TOVAR SA, PEREZ D, MALLO F, LOPEZ M, SENARIS R, CASANUEVA FF, DIEGUEZ C: Orexin A suppresses in vivo GH secretion. Eur J Endocrinol 150: 731-736, 2004.

SMART D, HAYNES AC, WILLIAMS G, ARCH JR: Orexins and the treatment of obesity. Eur J Pharmacol 440: 199-212, 2002.

SWEET DC, LEVINE AS, BILLINGTON CJ, KOTZ CM: Feeding response to central orexins. Brain Res 821: 535538, 1999.

TOMASIK PJ, SPODARYK M, SZTEFKO K: Plasma concentrations of orexins in children. Ann Nutr Metab 48: $215-$ $220,2004$.

YAMADA H, OKUMURA T, MOTOMURA W, KOBAYASHI Y, KOHGO Y: Inhibition of food intake by central injection of anti-orexin antibody in fasted rats. Biochem Biophys Res Commun 267: 527-531, 2000.

YAMANAKA A, KUNII K, NAMBU T, TSUJINO N, SAKAI A, MATSUZAKI I, MIWA Y, GOTO K, SAKURAI T: Orexin-induced food intake involves neuropeptide Y pathway. Brain Res 859: 404-409, 2000.

YANAGISAWA M, BEUCKMANN CT: Orexins: from neuropeptides to energy homeostasis and sleep/wake regulation. J Mol Med 80: 329-342, 2002.

\section{Reprint requests}

Jiř́ Bronský, Department of Pediatric Gastroenterology, Pediatric Clinic, $2^{\text {nd }}$ Medical Faculty, Charles University and University Hospital Motol, V Úvalu 84, 15006 Prague 5, Czech Republic. Tel.: +420 22443 2092, Fax: +420 22443 2020. E-mail: bronsky@email.cz 